\title{
Prevalence and distribution of intestinal parasites in stray dogs in the northwest area of Mexico
}

\author{
Enrique Trasviña-Muñoz ${ }^{a}$, Gilberto López-Valencia ${ }^{a^{*}}$, Pedro Álvarez Centeno ${ }^{b}$, \\ Sergio A. Cueto-González ${ }^{\mathrm{a}}$, Francisco J. Monge-Navarroa ${ }^{\text {a }}$ Luis Tinoco-Gracia ${ }^{\text {a, }}$ \\ Karla Núñez-Castro ${ }^{a}$, Paulina Pérez-Ortiz ${ }^{\text {a }}$ Gerardo E. Medina-Basultoa, \\ Alma R. Tamayo-Sosa ${ }^{a}$, Daniel Gómez-Gómez ${ }^{\mathrm{a}}$
}

\begin{abstract}
Zoonotic parasitic infections are a major global public and veterinary health problem and widespread among stray dogs. The objective of this study was to establish the prevalence of intestinal parasites in stray dogs in the urban, rural and coastal areas of Mexicali County in northwest Mexico. In 2014, from January to December, 380 stray dogs were captured. The entire small intestine, cecum and faeces samples were collected and examined by using simple zinc sulfate flotation and Lugol's solution staining. Data were statistically analysed. Overall, about $21.5 \%$ of examined dogs were found positive for intestinal parasites. Toxocara canis was the most frequent detected parasite, with a prevalence of $7.1 \%$, followed by Toxascaris leonina (5.5\%), Cystoisospora spp. (5.0\%), Taenia spp. (3.9\%) and Dipylidium caninum (2.8\%). Dogs were more frequently found to be infected with a single genus of intestinal parasite $(18.7 \%)$ than co-infected $(2.8 \%)$. Intestinal parasites were more prevalent in samples from the coastal area $(25 \%)$ than in those from the rural $(24.4 \%)$ and urban $(20.6 \%)$ areas, however, only statistical association was found between capture area and specific intestinal parasitic infection. There were significant differences in the prevalence of taeniasis among two age groups $(P<0.01)$. A seasonal peak of prevalence for intestinal parasitic infections was found during spring $(P<0.05)$, corresponding with a seasonal peak of prevalence of $T$. canis $(P<0.05)$. The wide range of isolated parasites indicated that people residing in this area are at risk of exposure to these potentially hazardous zoonotic pathogens.
\end{abstract}

Key words: toxocariasis, taeniasis, Mexico, public health.

RESUMEN. Las infecciones zoonóticas parasitarias son un problema global público y para la medicina veterinaria, siendo diseminadas por perros callejeros. El objetivo del estudio fue determinar la prevalencia de parasitosis intestinales en perros callejeros de la zona urbana, rural y costera del municipio de Mexicali, noroeste de México. En 2014, entre enero y diciembre, se capturaron 380 perros. Se colectó el intestino, ciego y heces y se examinaron utilizando flotación con sulfato de zinc y tinción con la solución de Lugol. Los datos fueron analizados estadísticamente. En general, alrededor del 21,5\% de los perros examinados fueron positivos a parásitos intestinales. Toxocara canis fue el parásito más frecuentemente, con una prevalencia del 7,1\%, seguido por Toxascaris leonina (5,5\%), Cystoisospora spp. (5,0\%), Taenia spp. (3,9\%) y Dipylidium caninum (2,8\%). Los perros fueron más frecuentemente encontrados infectados con un solo género de parásito intestinal $(18,7 \%)$ que coinfectados $(2,8 \%)$. Las parasitosis intestinales fueron más prevalentes en muestras de la costa (25\%) que del área rural $(24,4 \%)$ y urbana $(20,6 \%)$, sin embargo solo se encontró asociación estadística entre el área de captura y las parasitosis intestinales específicas. Hubo diferencias significativas en la prevalencia de taeniasis entre los dos grupos de edad $(P<0,01)$. El pico estacional de la prevalencia de infecciones parasitarias intestinales se encontró durante la primavera $(P<0,05)$, correspondiendo con el pico estacional de $T$. canis $(P<0,05)$. La amplia gama de parásitos aislados indicó que las personas que residen en esta zona están en riesgo de exposición a estos patógenos zoonóticos potencialmente peligrosos.

Palabras clave: toxocariasis, teniasis, México, salud pública.

\section{INTRODUCTION}

Since humans began to live in close proximity to companion animals, zoonotic diseases have become a major problem for human health (Day et al 2012). Dogs can harbor a wide range of intestinal parasites, some of which have a zoonotic potential, such as Toxocara canis, Dipylidium caninum and Taenia multiceps (Weese et al 2011). Human parasitic infections typically occur following ingestion of infective eggs from contaminated

\footnotetext{
Accepted: 10.03.2017.

anstitute for Research in Veterinary Sciences, Autonomous University of Baja California, Baja California, Mexico.

bMunicipal Animal Control Centre, Municipal Health Services, Mexicali, Baja California, Mexico.

*Corresponding author: G López-Valencia; gilbertolopez@uabc.edu.mx.
}

water or soil, ingestion of infected meat from the cattle or ingestion of inadequately washed or cooked fruits and vegetables (Lee et al 2010). Public concern over canine parasitic diseases has been aggravated by the high and uncontrolled number of stray dogs in urban areas that shed parasite eggs and oocysts, representing a source of infection for humans (Traub et al 2005, MartínezBarbabosa et al 2008). Furthermore, dogs infected with Taenia species, can also infect livestock leading to the development of cysts in their tissues and being the cause of monetary losses due to the confiscation of infected carcases in abattoirs (Wondimu et al 2011).

In previous studies conducted in the municipality of Mexicali in northwest Mexico, the overall prevalence of parasitic diseases in stray dogs was $66 \%$ (Luna et al 1981). In 2007, another report showed a $56.1 \%$ serologic prevalence of toxocariasis in domestic dogs (TinocoGracia et al 2007 ) and contamination with Toxocara 
canis eggs in $62.5 \%$ of soil samples collected from public parks and playgrounds where the presence of domestic and stray dogs was common and frequent (Tinoco-Gracia et al $2007^{\mathrm{b}}$ ). Since then, there are no other reports to follow up the prevalence of parasitic diseases in stray dogs from Mexicali. During 2014, the Municipal Animal Control Center (CEMCA) reported a total of 14,368 dogs captured. To control and reduce the prevalence rate of zoonotic parasitic infections, comprehensive data about their epidemiological features are required. Therefore, the present investigation evaluated the prevalence and distribution of intestinal parasites in stray dogs in the different areas of Mexicali, with special attention to potential zoonotic parasites.

\section{MATERIAL AND METHODS}

\section{ETHICS STATEMENT}

All animal handling procedures were conducted following national code NOM-033-ZOO-1995 and the local regulation for the control of domestic animals (Ayuntamiento de Mexicali 2009). All procedures were also approved by the Institutional Committee for Animal Ethics, represented by the Academic Group of Animal Health and the Academic Group for Diagnosis of Infectious Diseases, both part of the Instituto de Investigaciones en Ciencias Veterinarias (IICV), Universidad Autónoma de Baja California (UABC).

\section{DATA COLLECTION}

Sex (male and female), dental age (younger and older than one year of age), size (small, medium and large dogs) and capture zone (urban, rural and coastal area from the municipality of Mexicali) were recorded at the time of sample collection and were used to establish associations with parasitic infections.

\section{SAMPLE SIZE DETERMINATION}

Sample size was determined using the formula described by Thrusfield (2007), with a $95 \%$ confidence interval. The expected prevalence of intestinal parasitic infections in dogs from Mexicali was 66\% (Luna 1981).

$$
\frac{n=1.96^{2} \times p(1-p)}{d^{2}}
$$

Where:

$\mathrm{n}=$ required sample size

$\mathrm{p}=$ expected prevalence $66 \%$

$\mathrm{d}=$ desired absolute precision $5 \%$

The minimum sample size was 344 , but the final sample size was established at 380 .
SAMPLE COLLECTION AND PARASITOLOGICAL PROCEDURES

A cross-sectional, epidemiological study was conducted in the Mexicali County from January to December 2014. The city of Mexicali is situated along the state's northern border with California and is the northernmost city in Latin America; it is located at latitude $32^{\circ} 37^{\prime} 40^{\prime \prime} \mathrm{N}$ and longitude $115^{\circ} 27^{\prime} 16^{\prime \prime} \mathrm{W}$. In order to detect and identify intestinal parasites directly into the small intestine, cecum and faeces were collected from stray dogs captured by the CEMCA from three areas of the Mexicali municipality: (1) the urban area of the city of Mexicali City, (2) the rural area of the Mexicali Valley and (3) the coast area of San Felipe in the Sea of Cortez. An average of 32 dogs were randomly selected per month and location with a total of 380 dogs sampled. After the personnel from CEMCA had euthanised the dogs following their approved procedure, dog carcasses were dissected to remove the small intestine and cecum. Stool samples were taken directly from the rectum. Small intestine, cecum and stool samples were placed in plastic bags, identified, stored at $4{ }^{\circ} \mathrm{C}$ and sent to the Laboratory of Parasitology in IICV and analysed for the detection and identification of intestinal parasites.

To detect and identify intestinal parasites, the small intestine and cecum were opened longitudinally for examination. Faecal samples were examined for eggs and oocysts by zinc sulfate flotation technique (specific gravity 1.250), and lugol's iodine was added to help in the identification of protozoan cysts and coccidial oocysts (Besné et al 2005). Helminths were detected in intestines and feces, however some tapeworms were not detected in faeces but they were detected in the intestine, for this reason eggs per gram (EPG) are not presented and protozoa were identified in stool. Morphological identification of adult parasites, eggs and oocysts were performed as described by Zajac et al (2012).

\section{STATISTICAL ANALYSIS}

Descriptive statistics indicators were calculated to establish the frequencies of the overall cases of parasitic intestinal infections, for each specific parasite, for single infected and co-infected samples, for capture zone and seasonal trend of parasitic infections. Inferential analysis were performed using Statistix $9 \circledR$ software, Chi square $\left(\mathrm{x}^{2}\right)$ estimation were performed to establish associations between parasitic infections and analysed variables, odds ratio (OR) were also calculated with $95 \%$ confidence intervals.

\section{RESULTS}

Out of 380 faecal samples analysed for the presence of intestinal parasites, $82(21.5 \%)$ were positive for at least one parasitic species. The prevalence of single 
intestinal parasitic infections was $18.7 \%$ (71 of 380), being $T$. canis the most frequent parasite observed in this group of animals. In contrast, 2.8\% (11 of 380 samples) of dogs were infected by at least two different species of parasites, being $T$. canis and T. leonina the most frequent observed co-infection (table 1). The overall prevalence of protozoa and helminths was 5\% (19 of 380) and 17.1\% (65 of 380), respectively. T. canis was the most common helminth (7.1\%), followed by T. leonina (5.5\%), Taenia spp. (3.9\%) and Dypilidium caninum (2.9\%). Based on capture area of the dogs, the largest frequency of infection with intestinal parasites was found in the coastal area of San Felipe, with an overall prevalence of $25 \%$. In contrast, the lowest frequency was detected in the urban area of the city of Mexicali, with a prevalence of $20.6 \%$ (table 2). However, no significant differences were found between the three different areas and overall prevalence, but statistical association was found between capture area and specific intestinal parasitic infection, as demonstrated by the presence of Cystoisospora spp. only in the urban area $(P<0.05)$. Taeniasis showed a higher prevalence in the rural area (14.2\%) compared with the urban $(2.7 \%)$ and coastal areas $(0 \%)(P<0.001)$, with an OR of 5.8 (table 3). In contrast, the coastal area of San Felipe was characterised by a high prevalence of dypilidiasis (20\%) $(P<0.001)$, as well as a high risk of infection with an OR of 72.5 (table 4). Concerning seasonal trend, only T. canis showed a higher occurrence $(16.2 \%)$ during spring season $(P<0.001)$ (table 5$)$. The overall seasonal prevalence of parasitic infections was higher in spring $(27.5 \%)$ than in summer season $(15.4 \%)$, with an odds ratio of 2.0, indicating twice the risk of parasitic infections during this season (table 6). No significant differences were found between intestinal parasitic infections and sex and size of dogs. However the variable age showed a significant difference for Taenia spp. $(P<0.01)$ indicating higher prevalence in dogs older $(5.7 \%)$ than one year $(0 \%)$ (table 7).

Table 1. Samples detected with one or two genera of parasites.

\begin{tabular}{lcc}
\hline Detected parasites & Positives/analysed & Prevalence \\
\hline Single infection & & \\
Toxocara canis & $19 / 380$ & $5.0 \%$ \\
Toxascaris leonina & $12 / 380$ & $3.1 \%$ \\
Cystoisospora spp. & $17 / 380$ & $4.4 \%$ \\
Taenia spp. & $13 / 380$ & $3.4 \%$ \\
Dipylidium caninum & $10 / 380$ & $2.6 \%$ \\
Subtotal & $71 / 380$ & $18.7 \%$ \\
Co-infection & & \\
Toxocara canis + Toxascaris leonina & $6 / 380$ & $1.5 \%$ \\
Toxocara canis + Taenia spp. & $2 / 380$ & $0.5 \%$ \\
Toxascaris leonina + Cystoisospora canis & $2 / 380$ & $0.5 \%$ \\
Dipylidium caninum + Toxascaris leonina & $1 / 380$ & $0.2 \%$ \\
Subtotal & $11 / 380$ & $2.8 \%$ \\
Total & $82 / 380$ & $21.5 \%$ \\
\hline
\end{tabular}

Table 2. Prevalence by capture zone.

\begin{tabular}{lccrc}
\hline Total $(\mathrm{n}=380)$ & $\begin{array}{c}\text { Mexicali City } \\
(\mathrm{n}=291)(\%)\end{array}$ & $\begin{array}{c}\text { Mexicali Valley } \\
(\mathrm{n}=49)(\%)\end{array}$ & $\begin{array}{c}\text { San Felipe Seaport } \\
(\mathrm{n}=40)(\%)\end{array}$ & 5 \\
\hline Toxocara canis & 7.5 & 6.1 & 2.5 & 0.80 \\
Toxascaris leonina & 6.1 & 4.0 & 0 & 0.56 \\
Cystoisospora spp. & 6.5 & 0 & 0 & $0.047 *$ \\
Taenia spp. & 2.7 & 14.2 & 20 & $0.0003 * * *$ \\
Dipylidium caninum & 0.3 & 4.0 & 25 & $0.0000^{* * *}$ \\
Overall prevalence & 20.6 & 24.4 & 0.71 \\
\hline
\end{tabular}

Comparison of overall and specific prevalences by capture zone. Results of $\chi^{2}$ test.

$* P<0.05$.

$* * P<0.01$.

$* * * P<0.001$. 
Table 3. Magnitude of association between taeniasis and capture zone.

\begin{tabular}{lcccccc}
\hline Capture zone & Taenia + & Taenia - & Total & OR & $95 \%$ IC & P \\
\hline Mexicali City & 8 & 283 & 291 & 1.0 & Reference & - \\
Mexicali Valley & 7 & 42 & 49 & 5.8 & $2.0-17.1$ & $0.0003 * * *$ \\
San Felipe & 0 & 40 & 40 & ND & ND & \\
Total & 15 & 365 & 380 & & & \\
\hline
\end{tabular}

Comparison of capture zone by taeniasis cases. Results of $\chi^{2}$ test and odds ratio estimated with confidence intervals (IC) of $95 \%$.

$* P<0.05$.

$* * P<0.01$.

$* * * P<0.001$.

Table 4. Magnitude of association between dipylidiasis and capture zone.

\begin{tabular}{lcccccc}
\hline Capture zone & Dipylidium + & Dipylidium - & Total & OR & $95 \%$ IC & P \\
\hline Mexicali City & 1 & 290 & 291 & 1.0 & Reference & - \\
Mexicali Valley & 2 & 47 & 49 & 12.3 & $(1.0-138.8)$ & $0.0096^{* * *}$ \\
San Felipe & 8 & 32 & 40 & 72.5 & $(8.7-598.4)$ & $0.0000^{* * *}$ \\
Total & 11 & 369 & 380 & & & \\
\hline
\end{tabular}

Comparison of capture zone by dipylidiasis cases. Results of $\chi^{2}$ test and odds ratio estimated with confidence intervals (IC) of $95 \%$.

$* P<0.05$.

$* * P<0.01$.

$* * * P<0.001$

Table 5. Prevalence by season of the year.

\begin{tabular}{lccccc}
\hline Total $(\mathrm{n}=380)$ & $\begin{array}{c}\text { Spring } \\
(\mathrm{n}=80)(\%)\end{array}$ & $\begin{array}{c}\text { Summer } \\
(\mathrm{n}=110)(\%)\end{array}$ & $\begin{array}{c}\text { Autumn } \\
(\mathrm{n}=126)(\%)\end{array}$ & $\begin{array}{c}\text { Winter } \\
(\mathrm{n}=64)(\%)\end{array}$ & $\begin{array}{c}\mathrm{P} \\
\text { Toxocara canis }\end{array}$ \\
Toxascaris leonina & 16.2 & 6.3 & 0.7 & 9.3 & $0.0004 * * *$ \\
Cystoisospora spp. & 7.5 & 1.8 & 8.7 & 3.1 & 0.08 \\
Taenia spp. & 8.7 & 1.8 & 6.3 & 3.1 & 0.12 \\
Dipylidium caninum & 2.5 & 1.8 & 5.9 & 0.3 & 0.08 \\
Overall prevalence & 0 & 3.6 & 24.6 & 18.7 & 0.053 \\
\hline
\end{tabular}

Comparison of overall and specific prevalences by season of the year. Results of $\chi^{2}$ test.

$* P<0.05$.

$* * P<0.01$.

$* * * P<0.001$.

Table 6. Magnitude of association between season and overall prevalence.

\begin{tabular}{lcccccc}
\hline Season & Parasitized & Not parasitized & Total & OR & $95 \%$ IC & P \\
\hline Summer & 17 & 93 & 110 & 1.0 & Reference & - \\
Autumn & 31 & 95 & 126 & 1.7 & $(0.9-3.4)$ & 0.08 \\
Winter & 12 & 52 & 64 & 1.2 & $(0.5-2.8)$ & 0.57 \\
Spring & 22 & 58 & 80 & 2.0 & $(1.0-4.2)$ & $0.04 *$ \\
Total & 82 & 298 & 380 & & &
\end{tabular}

Comparison of the season of the year by the overall prevalence. Results of $\chi^{2}$ test and odds ratio estimated with confidence intervals (IC) of $95 \%$.

$* P<0.05$

$* * P<0.01$

$* * * P<0.001$ 
Table 7. Prevalence by age.

\begin{tabular}{lccc}
\hline Total $(\mathrm{n}=380)$ & $\begin{array}{c}\text { Younger than } 1 \mathrm{yr} \\
(\mathrm{n}=117)(\%)\end{array}$ & $\begin{array}{c}\text { Older than } 1 \mathrm{yr} \\
(\mathrm{n}=263)(\%)\end{array}$ & $\mathrm{P}$ \\
\hline Toxocara canis & 4.2 & 8.3 & 0.15 \\
Toxascaris leonina & 4.2 & 6.0 & 0.47 \\
Cystoisospora spp. & 5.9 & 4.5 & 0.55 \\
Taenia spp. & 0 & 5.7 & $0.0084^{* *}$ \\
Dipylidium caninum & 1.7 & 3.4 & 0.35 \\
Overall prevalence & 16.2 & 23.9 & 0.09 \\
\hline
\end{tabular}

Comparison of overall and specific prevalences by age. Results of $\chi^{2}$ test. $* P<0.05$.

$* * P<0.01$.

$* * * P<0.001$.

\section{DISCUSSION}

The overall prevalence of intestinal parasitic infections found in this study was $21.5 \%$. Previous studies conducted in Mexico showed some differences in the prevalence of intestinal parasites, such as a prevalence of $78 \%$ in stray dogs from Queretaro District (Fernández and Cantó 2002). Furthermore, other countries found higher prevalence of intestinal parasitic infections compared with this study. A study conducted in Spain reported an overall prevalence of $71.3 \%$; while prevalences of $86.8 \%, 58.5 \%, 43$ to $57.4 \%$ and $39.2 \%$ were found respectively in Ethiopia, Brazil, Italy and Japan (Martínez-Moreno et al 2007, Katagiri and Oliveira 2008, Paulos et al 2012, Kimura et al 2013, Zanzani et al 2014). These differences could be due to the fact that most of the geographic location of Mexicali has a desert climate where temperatures during late spring, summer and early autumn vary from $36^{\circ} \mathrm{C}$ to $50{ }^{\circ} \mathrm{C}$ with low humidity (Servicio Meteorológico Nacional 2010). In addition to high temperatures, these climate conditions lead to a moisture deficit which may slow or even suppress the development of parasite eggs resulting in lower rate of viability (table 7), making it difficult for parasites to develop and survive in those extreme environmental conditions to produce infection (Polley and Thompson 2009). The most frequently detected parasite in the positive samples $(\mathrm{n}=82)$ was $T$. canis with $7.1 \%$ of all cases. It has been documented that $T$. canis eggs are very resistant to extreme weather conditions and chemical agents (TrilloAltamirano et al 2003). T. canis also was more prevalent during the spring season when the soils are less dry due the climate in that season, having more chances to survive (Treonis and Wall 2005). Additionally, T. canis has different routes of infection, such as oral, transplacental, transmammary, and is well known that it can be transmitted by paratenic hosts, which facilitate the perpetuation of that parasite in the ecosystem (Díez-Baños et al 1999). The prevalence of $T$. canis found in this study was similar to that reported in a previous study conducted in the State of Yucatan, southeast Mexico, with an overall prevalence of 7.7\% (Rodríguez-Vivas et al 2001), but lower than that reported in Queretaro, in the central part of Mexico with a prevalence of $13.9 \%$ (Fernández and Cantó 2002), the Distrito Federal, Mexico's national capital city with a prevalence of 14\% (Núñez et al 2009) and Campeche, also in southeast Mexico with a prevalence of $14.4 \%$ (Encalada-Mena et al 2011).

Cystoisospora spp. was found only in the urban area of Mexicali. This parasite does not represent a zoonotic risk but it is important for dogs because it can damage the intestinal epithelium, causing liquid diarrhea with or without blood, dehydration, weight loss, vomiting, lethargy and anorexia (Miró-Corrales et al 1999). Another important finding in our study was the detection of D. caninum in $2.8 \%$ of cases. The prevalence of this parasite was higher than that reported in Yucatán (Rodríguez-Vivas et al 2001) but lower than in Queretaro (Fernández and Cantó 2002). Dipylidiasis is an important problem for public health, because it can infect young children causing a variety of gastrointestinal disorders (Neafie and Marty 1993). The prevalence of Taenia spp. established in 3.9\% in this study, was lower than the 5.4\% reported in Queretaro (Fernández and Cantó 2002). The presence of Taenia spp. transmitted by dogs is important for public health. Larval stages of Taenia serialis and T. multiceps (King 2005) can form unilocular cysts in the central nervous system, eye, subcutaneous tissue and muscle tissue (Ing et al 1998). In this study we have identified an association $(P<0.05)$ between the cases of taeniasis and the capture zone (rural area of Mexicali). A possible explanation for this, is that the rural area of the Mexicali County is a zone characterised by poor sanitary conditions, where dogs lives in close contact with livestock, rodents and lagomorphs, animal species known to harbor Taenia spp. serving as intermediary hosts to complete their life cycle (Weese et al 2011). This finding is particularly important because in the rural area of the Mexicali County many large feedlot operations take place, with over 300,000 heads of cattle being fattened each year to send selected meat cuts to local and international markets (SEFOA, 2016), which can be at risk of being infected by contamination of food or water supplies with Taenia spp. 
eggs carried by dogs. For example, infection with Taenia hydatigena transmitted by dogs can lead to the development of cysts in tissues of the cattle and being the cause of organs, meat or carcass confiscation or condemnation during sanitary inspection at abattoirs, causing monetary losses to producers. (Wondimu et al 2011).

No significant differences were detected between parasitic infections and the variables of sex and size of dogs, however, an association $(P<0.05)$ was identified between dogs $>1$ year and taeniasis. The cause for this might be that adult dogs move farther distances for feeding and breeding, giving them great chance to get in contact with material contaminated with eggs or get infected after hunting and feeding from rodents or lagomorphs infected with larval stages of Taenia spp. (Ajlouni et al 1984).

Dipylidiasis was found associated $(P<0.05)$ with presence only in the coastal area of San Felipe, over 100 miles away from urban and rural areas of the municipality and where the mild and more humid climate conditions are more favorable, and intermediary hosts such as the fleas Ctenocephalides canis, Ctenocephalides felix, Pulex irritans and the louse Trichodectes canis, can develop and survive to complete the biological cycle of $D$. caninum (Sánchez-Acedo et al 1999). Considering the public health implications of dipylidiasis, it is necessary to conduct an epidemiological study in this area to identify and evaluate the impact of the intermediary host for dipylidiasis.

According to the results of this study, it is concluded that one in five stray dogs carried at least one type of intestinal parasite. Toxocara canis was the most common parasite found in single infected cases (19/380) and co-infected cases (8/380). Additionally, parasites of importance to public health were identified such as T. canis, T. leonina, D. caninum and Taenia spp. Toxocara canis was the most frequent parasite detected, which implies a higher risk to the population. Further studies are needed on the impact on the population of Mexico. The rural area of the Mexicali valley is the region with higher risk for taeniasis infections mainly because of the large number of stray dogs living in close proximity with cattle management systems. Infection with Taenia spp. in carcasses during post-mortem inspection is difficult to achieve, suggesting that an undetermined number of carcasses pass the screening as being free of parasites and the meat is distributed and consumed in both domestic and international wholesale markets, thus increasing the risk of zoonotic transmission of Taenia spp through infected meat. The low level of sensitivity inherent to the sanitary post-mortem examination (Abuiser et al 2006), along with the lower rates of detection and official reporting of this type of parasite at local slaughterhouses and TIF abattoirs, generate an area of opportunity for the introduction and instrumentation of preventive medicine strategies in dogs and cattle that allows to reduce the risk of transmission to the human.

To control and reduce the problem of zoonotic intestinal parasitic infections both public and veterinary health services should work together, and animal ownership laws should be implemented in Mexico with severe fines for people who do not comply with them, in order to reduce the problem of stray dogs and intestinal parasitic zoonoses.

\section{ACKNOWLEDGEMENTS}

This work is part of the requisites to obtain the grade of Doctor en Ciencias Agropecuarias of the present first author (Universidad Autónoma de Baja California). We thank the Animal Control Municipal Centre of Mexicali and students Priscila Nataly Ríos López and Rocío Yazmín Cazares from the Autonomous University of Baja California for their collaboration in this work.

\section{REFERENCES}

Abuiser S, Epe C, Schnieder T, Klein G, Kuhne M. 2006. Visual diagnosis of Taenia saginata cysticersosis during meat inspection: Is it unequivocal?. Parasitol Res 99, 405-409.

Ajlouni AQ, Saliba EK, Disi AM. 1984. Intestinal cestodes of stray dogs in Jordan. Zeitschrift für Parasitenkd 70, 203-210.

Ayuntamiento de Mexicali, México. 2009. Reglamento para el control de los animales domésticos del municipio de Mexicali, Baja California. Periódico Oficial del Estado de Baja California.

Besné MA, Figueroa CJA, Quiroz RH, Ramírez GA, Ramos ME. 2005. Manual de Prácticas de laboratorio de parasitología. $1^{\mathrm{a}} \mathrm{ed}$. UNAM, Ciudad de México, México.

Day JM, Breitschwerdt E, Cleaveland S, Karkare U, Khanna C, et al. 2012. Surveillance of zoonotic infectious disease transmitted by small companion animals. Emerg Infect Dis 18, 2-10.

Díez-Baños P, Díez-Baños N, Morrondo-Pelayo MP. 1999. Parasitosis del perro y el gato: nematodosis. En: Cordero del Campillo M, Rojo-Vázquez FA, Fernández-Martínez AR, Hernández-Rodríguez $\mathrm{S}$, López-Cozar IN, et al (eds). Parasitología veterinaria. $1^{\mathrm{a}}$ ed. McGraw-Hill Interamericana, Madrid, España, Pp 636-638.

Encalada-Mena LA, Duarte-Ubaldo EI, Vargaz-Magaña JJ, GarcíaRamírez MJ, Medina-Hernández RE. 2011. Prevalencia de parásitos gastroentéricos de cánidos en la ciudad de Escárcega, Campeche, México. Trópico Húmedo 27, 209-217.

Fernández-Campos F, Cantó-Alarcón GJ. 2002. Intestinal helminth frequency in stray dogs sacrificed in the City of Queretaro, in the State of Queretaro, in Mexico. Vet México 33, 247-253.

Ing MB, Schantz PM, Turner JA. 1998. Human coenurosis in North America: case reports and review. Clin Infect Dis 27, 519-523.

Katagiri S, Oliveira-Sequeira TC. 2008. Prevalence of dog intestinal parasites and risk perception of zoonotic infection by dog owners in São Paulo State, Brazil. Zoonoses Public Health 55, 406-413.

Kimura A, Morishima Y, Nagahama S, Horikoshi T, Edagawa A, et al. 2013. A coprological survey of intestinal helminthes in stray dogs captured in Osaka Prefecture, Japan. J Vet Med Sci 75, 1409-1411.

King CH. 2005. Cestodes (tapeworms). In: Mandell L, Bennett JE, Dolin R. Principles and Practice of Infectious Diseases. $7^{\text {th }}$ ed. Churchill Livingstone, Philadelphia, USA, Pp 3290-3293.

Lee AC, Schantz PM, Kazacos KR, Montgomery SP, Bowman DD. 2010. Epidemiologic and zoonotic aspects of ascarid infections in dogs and cats. Trends Parasitol 23, 155-161.

Luna D. 1981. Estudio parasitológico realizado en los perros sacrificados en el Centro Antirrábico de Mexicali, Baja California, durante los meses de mayo y junio de 1981. Tesis Maestría, Instituto de Investigación en Ciencias Veterinarias, Universidad Autónoma de Baja California, México.

Martínez-Barbabosa I, Gutiérrez-Cárdenas EM, Alpizar-Sosa EA, Pimienta-Lastra R de J. 2008. Contaminación parasitaria en heces de perros, recolectadas en calles de la ciudad de San Cristóbal de Las Casas, Chiapas, México. Vet Mex 39, 173-180. 
Martínez-Moreno FJ, Hernández S, López-Cobos E, Becerra C, Acosta I, et al. 2007. Estimation of canine intestinal parasites in Córdoba (Spain) and their risk to public health. Vet Parasitol 143, 7-13.

Miró-Corrales G, Sánchez-Acedo C, Quílez J, del Cacho E. 1999. Parasitosis del perro y el gato: coccidiosis sensu lato, amebosis y balandisiosis. En: Cordero del Campillo M, Rojo-Vázquez FA, Fernández-Martínez AR, Hernández-Rodríguez S, López-Cozar IN, et al (eds). Parasitología veterinaria. $1^{\mathrm{a}}$ ed. McGraw-Hill Interamericana, Madrid, España, Pp 615-617.

Neafie RC, Marty AM. 1993. Unusual infections in humans. Clin Microbiol Rev 6, 34-56.

Núñez-Romero C, García-Contreras A del C, Mendoza-Martínez GD, TrilloCorona NC, Rarmírez-Durán N. 2009. Contaminación por Toxocara spp. en parques de Tulyehualco, México. Rev Cient 19, 253-256.

Paulos D, Addis M, Fromsa A, Mekibib B. 2012. Prevalence of gastrointestinal helminthes among dogs and owners perception about zoonotic dog parasites in Hawassa Town, Ethiopia. J Public Heal Epidemiol 4, 205-209.

Polley L, Thompson RC. 2009. Parasite zoonoses and climate change: molecular tools for tracking shifting boundaries. Trends Parasitol $25,285-291$.

Rodríguez-Vivas RI, Cob-Galera LA, Domínguez-Alpizar JL. 2001. Frecuencia de parásitos gastrointestinales en animales domésticos diagnosticados en Yucatán, México. Rev Biomed 12, 19-25.

Sánchez-Acedo C, Quílez J, del Cacho E. 1999. Parasitosis del perro y el gato: cestodosis. En: Cordero del Campillo M, Rojo-Vázquez FA, FernándezMartínez A R, Hernández-Rodríguez S, López-Cozar IN, Díez-Baños P, Quiroz-Romero H, Carvalho-Varela M. Parasitología veterinaria. 1a ed. McGraw-Hill Interamericana, Madrid, España, Pp 629-631.

SEFOA, Secretaria de Fomento Agropecuario. 2016. Cuaderno Estadístico Pecuario de Baja California 2011-2015. Secretaría de Fomento Agropecuario, Mexcali, Baja California, México.

Servicio Meteorológico Nacional. 2010. Condiciones normales climatológicas: Estado de Baja California, Mexicali. Servicio Meteorológico Nacional, México.
Thrusfield M. 2007. Surveys. In: Veterinary Epidemiology. $3^{\text {rd }}$ ed. Blackwell Science, Iowa, USA, Pp 233.

Tinoco-Gracia L, Barreras-Serrano A, López-Valencia G, Tamayo-Sosa AR. 2007 . Seroprevalence and risk factors associated with larva migrans of Toxocara canis in dogs from Mexicali Baja California, Mexico. J Anim Vet Adv 6, 198-202.

Tinoco-Gracia L, Barreras-Serrano A, López-Valencia G, Tamayo-Sosa AR, Rivera-Henry M, et al. 2007 . Frequency of Toxocara canis eggs in public parks of the urban area of Mexicali, B.C., Mexico. J Anim Vet Adv 6, 430-434.

Traub RJ, Robertson ID, Irwin PJ, Mencke N, Thompson RC. 2005. Canine gastrointestinal parasitic zoonoses in India. Trends Parasitol 21, 42-48.

Treonis MA, Wall DH. 2005. Soil nematodes and desiccation survival in the extreme arid enviroment of the Antarctic dry valleys. Integr Comp Biol 45, 741-750.

Trillo-Altamirano M del P, Carrasco AJ, Cabrera R. 2003. Prevalencia de helmintos enteroparásitos zoonóticos y factores asociados en Canis familiaris en una zona urbana de la ciudad de Ica, Perú. Parasitol Latinoam 58, 136-141.

Weese JS, Peregrine AS, Anderson MEC, Fulford MB. 2011. Parisitic diseases. In: Weese JS, Fulford MB. Companion Animal Zoonoses. $1^{\text {st }}$ ed. Blackwell Science, Iowa, USA.

Wondimu A, Abera D, Hailu Y. 2011. A study on the prevalence, distribution and economic importance of Cysticercus tenuicollis in visceral organs of small ruminants slaughtered at an abattoir in Ethiopia. Vet Med Anim Heal 3, 67-74.

Zajac AM, Conboy GA, Greiner EC, Smith SA, Snowden KF. 2012. Fecal examination for the diagnosis of parasitism. In: Veterinary Clinical Parasitology. $8^{\text {th }}$ ed. Blackwell Science, Iowa, USA.

Zanzani SA, Gazzonis AL, Scarpa P, Berrilli F, Manfredi MT. 2014. Intestinal parasites of owned dogs and cats from metropolitan and micropolitan areas: prevalence, zoonotic risks, and pet owner awareness in northern Italy. Biomed Res Int 2014, 1-10. 
